\title{
A cautionary note: Toxicity of polyethylene glycol 200 injected intraperitoneally into mice
}

Laboratory Animals 2020, Vol. 54(4) 391-396 (C) The Author(s) 2019 Article reuse guidelines: sagepub.com/journals-permissions DOI: $10.1177 / 0023677219873684$ journals.sagepub.com/home/lan

(SAGE

\author{
Wilko Thiele ${ }^{1,2} \oplus$, Lenka Kyjacova ${ }^{1}$, Almut Köhler ${ }^{3}$ and \\ Jonathan P Sleeman ${ }^{1,2}$
}

\begin{abstract}
The parenteral administration of hydrophobic substances in vivo requires the use of organic solvents to ensure sufficient solubility and avoid precipitation. Dimethyl sulfoxide is commonly used for this purpose. Based on the common assumption that polyethylene glycol (PEG) is non-toxic, our local regulatory authorities recently recommended the use of PEG instead. However, mice injected intraperitoneally (i.p.) with PEG 200 at a dose of $8 \mathrm{~mL} / \mathrm{kg}$ (i.e. $9 \mathrm{~g} / \mathrm{kg}$ ) did not tolerate PEG 200 well, and half of the animals had to be euthanized. Our results demonstrate that although PEG 200 is generally considered to be harmless, it can be toxic when injected i.p. and is painful for the recipient mice. Nevertheless, it can be used as a solvent for repeated i.p. injections in mice at a dose of $2 \mathrm{~mL} / \mathrm{kg}$ (i.e. $2.25 \mathrm{~g} / \mathrm{kg}$ ) without obvious signs of systemic toxicity.
\end{abstract}

\section{Keywords}

dosing/sampling, ethics and welfare, injection, organisms and models, pain, rodents, techniques

Date received: 21 September 2018; accepted: 13 August 2019

\section{Introduction}

To minimise the suffering of experimental animals, solvents for injections should ideally be isotonic, used at body temperature and have a neutral $\mathrm{pH}$ of $7.0-7.3 .^{1}$ However, alternative solvents have to be employed if substances are poorly soluble in aqueous solution.

Dimethyl sulfoxide (DMSO; CAS number 67-68-5) is commonly used as a vehicle for hydrophobic substances to improve their solubility and avoid precipitation (Figure 1(a)). DMSO has a relatively low toxicity when applied systemically, and is rapidly cleared from the circulation and tissues. ${ }^{2,3}$ However, the injection of DMSO causes transient pain. Moreover, DMSO influences a variety of biological processes, and induces several side effects, limiting its range of applicability. ${ }^{4}$

Polyethylene glycols (PEGs; $\alpha$-Hydro- $\omega$-hydroxypoly(oxy-1,2-ethanediyl); CAS number 25322-68-3) are synthetic hydrophilic polyethers that consist of repeating ethylene oxide units. The general chemical formula of PEGs is $\mathrm{H}\left[\mathrm{OCH}_{2} \mathrm{CH}_{2}\right]_{n} \mathrm{OH}$, where $n$ represents the average number of oxyethylene groups (Figure 1(b)). ${ }^{2}$ Pharmaceutical grade PEG preparations are mixtures of polyethers with different molecular weights and chain lengths. The pharmaceutical term PEG 200 denotes a PEG mixture with an average molecular weight of $200 \mathrm{~g} / \mathrm{mol}$ and an average number of 4.2 oxyethylene groups. ${ }^{2}$ PEGs increase the solubility of poorly soluble compounds, and represent a potential alternative to other organic vehicles. ${ }^{2}$ They are widely used in pharmaceutical and cosmetic products, and are generally considered harmless, as they are non-toxic when applied orally or dermally. ${ }^{2,5-7}$ Furthermore, PEGs are used as food additives, and a daily intake of

\footnotetext{
${ }^{1}$ Universität Heidelberg, Medizinische Fakultät Mannheim, Mannheim, Germany

${ }^{2}$ KIT Campus Nord, Institut für Toxikologie und Genetik, Karlsruhe, Germany

${ }^{3} \mathrm{KIT}$, Stabsstelle Sicherheit und Umwelt, Karlsruhe, Germany
}

\section{Corresponding author:}

Wilko Thiele, Universitat Heidelberg, Medizinische Fakultat Mannheim, TRIDOMUS-Gebäude Haus C, Ludolf-Krehl-Str. 1317, Mannheim, 68167, Germany.

Email: wilko.thielelamedma.uni-heidelberg.de 


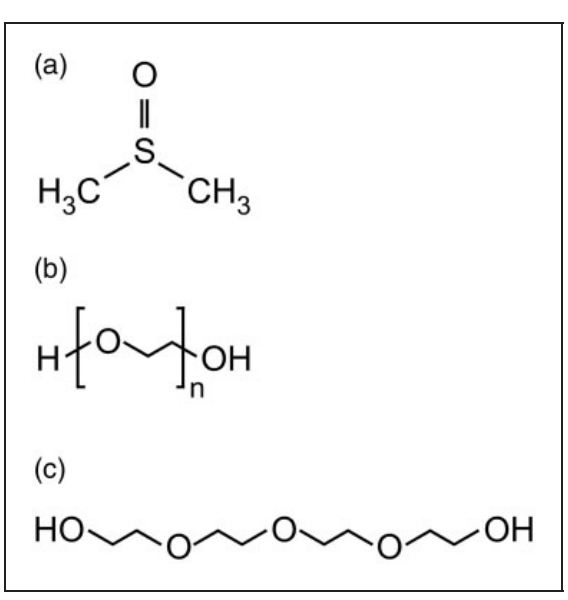

Figure 1. Chemical formulae of (a) dimethyl sulfoxide (DMSO), (b) polyethylene glycol (PEG) and (c) tetraethylene glycol. (b) In the case of PEG 200 that was used in our study, $n$ is 4.2 .

$10 \mathrm{mg} / \mathrm{kg}$ bodyweight is considered acceptable. ${ }^{8}$ However, reports about the toxicity of parenterally applied PEG in mice are scarce, and it is not widely accepted that the injection of PEG can be harmful. ${ }^{9-11}$

We have used DMSO as a solvent for preclinical parenteral in vivo studies for more than a decade. ${ }^{12-15}$ In 2017, we applied for permission to inject a test substance dissolved in DMSO intraperitoneally (i.p.) into tumour-bearing mice. However, the local regulatory authorities recommended that DMSO should be replaced with PEG, which they considered less harmful than DMSO. Having had no previous experience with the use of PEG, we followed this recommendation. Consequently, we used PEG 200 as a vehicle, and injected it at the approved dose. Unexpectedly, PEG 200 was not tolerated well by the mice, and half of them had to be euthanized. A subsequent literature search revealed that the toxicity of parenterally applied PEG had been reported more than five decades ago. ${ }^{10}$ As this literature is not widely read, here we highlight the often overlooked fact that PEG 200 is toxic with a $\mathrm{LD}_{50}$ of $7.5 \mathrm{~mL} / \mathrm{kg}$ in i.p. injections. ${ }^{10}$ Moreover, we observed that PEG 200 causes pain when injected i.p., even at a moderate dose.

\section{Materials and methods}

The animal experiment was approved by the local regulatory authorities, and was performed according to German legal requirements.

In control experiments, 16 (eight male) in-housebred C57BL/6 J mice aged 12-14 weeks (mean $\pm S D$ weight males: $29.9 \pm 2.2 \mathrm{~g}$; mean weight females: $22.9 \pm 1.6 \mathrm{~g}$ ) were randomly allocated to two groups with eight animals (four male) each. These groups were injected subcutaneously with either 5000 or 20,000 syngeneic B16-F10 cells in $100 \mu \mathrm{L}$ phosphatebuffered saline per animal. On day 4 post tumour cell inoculation, the animals were injected i.p. with $8 \mathrm{~mL} / \mathrm{kg}$ $(9 \mathrm{~g} / \mathrm{kg} ; \quad$ approximately $200 \mu \mathrm{L} /$ animal $)$ undiluted BioUltra PEG 200 (Sigma-Aldrich, Steinheim, Germany; lot number: BCBS0153V). The PEG 200 dose used was based on the solubility in PEG 200 of the chemical substance we intended to test in subsequent experiments with other groups of tumour-bearing mice. Treatment was suspended when we observed that the mice did not tolerate the injected PEG 200, and was resumed with the surviving mice on day 6 post tumour cell inoculation, with a reduced PEG 200 dose of $2 \mathrm{~mL} / \mathrm{kg} \quad(2.25 \mathrm{~g} / \mathrm{kg} ;$ approximately $50 \mu \mathrm{L} /$ animal). During the experiment, the animals were monitored at least four times per day. Tumour growth was assessed with a calliper twice per week. Animals were killed by cervical dislocation. The experimental scheme is depicted in Figure 2.

Mice were kept in groups of four in type III macrolon filtertop cages (Tecniplast, Hohenpeißenberg, Germany) containing SAFE fs 14 bedding (Rettenmaier \& Söhne, Rosenberg, Germany). Rat/ mouse extruded food (SSNIFF, Soest, Germany) and sterilised water acidified with $\mathrm{HCl}(\mathrm{pH}$ 2.8-3.1) were provided ad libitum. The specific pathogen-free area was kept at $20^{\circ} \mathrm{C}$ and $30-60 \%$ humidity on a $07: 00$ 20:00 hours light cycle. The health status of the animals in the facility is routinely assessed by a commercial veterinarian laboratory (mfd Diagnostics, Wendelsheim, Germany) in serological examinations every three months (epizootic diarrhoea of infant mice, mouse hepatitis virus, murine norovirus, minute virus of mice, Theiler's encephalomyelitis virus, Pasteurella pneumotropica) or annually (Clostridium piliforme, Mousepox, lymphocytic choriomeningitis virus, mouse adenovirus type 1 and type 2, Mycoplasma pulmonis, pneumonia virus of mice, Reovirus type 3, Sendai virus). The serology was found to be negative for the parameters tested.

\section{Results}

PEG 200 is not tolerated well by mice upon i.p. injection

PEG 200 was injected i.p. at $8 \mathrm{~mL} / \mathrm{kg}$ into the two control groups of tumour-bearing mice that only received the solvent PEG 200. Directly after the injection, all 16 animals had contracted flanks, and were obviously in pain. The flanks remained contracted, and the mice retreated to the corners of their cages, cowering apathetically. This status remained unchanged for several hours. Eight animals (three male) were moribund, and 


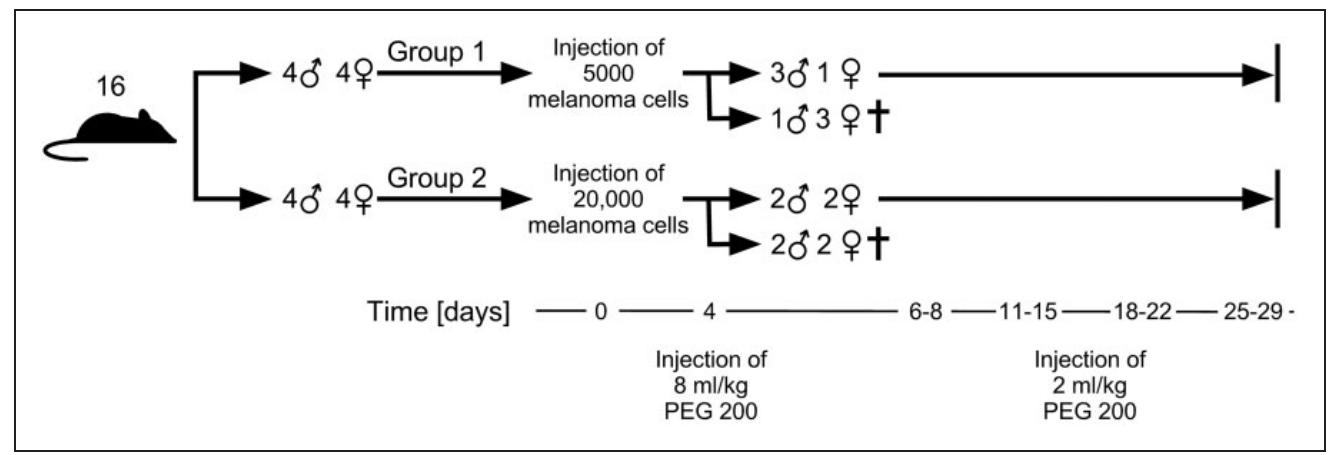

Figure 2. Schematic overview of how the experiment was performed. Two groups of mice, each with four male and four female animals, were used for the experiment. Group 1 was subcutaneously injected with 5000 syngeneic B16-F10 melanoma cells; group 2 received 20,000 B16-F10 cells. On day 4 post tumour cell inoculation, the animals were intraperitoneally injected with PEG 200 at $8 \mathrm{~mL} / \mathrm{kg}$. The animals did not tolerate the treatment well, and eight animals had to be euthanized by cervical dislocation. The remaining mice that had recovered from the first PEG injection were then injected again intraperitoneally on days $6-8,11-15,18-22$ and $25-29$ post tumour cell inoculation with PEG 200 at a dose of $2 \mathrm{~mL} / \mathrm{kg}$. The remaining animals were killed on day 29 post tumour cell injection by cervical dislocation.

Table 1. Overview moribund mice.

\begin{tabular}{llllll}
\hline & \multicolumn{2}{l}{$\begin{array}{l}\text { Number of } \\
\text { mice per group }\end{array}$} & & \multicolumn{2}{l}{$\begin{array}{l}\text { Number of } \\
\text { moribund mice }\end{array}$} \\
\cline { 2 - 3 } \cline { 5 - 6 } & 0 & & & 0 & + \\
\hline Group 1 & 4 & 4 & & 1 & 3 \\
Group 2 & 4 & 4 & & 2 & 2 \\
\hline
\end{tabular}

were euthanized 24 hours post injection (Table 1), whereas the remaining eight mice started to recover. The surviving animals completely recovered without any sign of discomfort by 48 hours after the injection.

In a subsequent extensive literature search, we found a single report from 1965 in which the toxicity of PEG was tested. ${ }^{10}$ The $\mathrm{LD}_{50}$ of PEG 200 was $7.5 \mathrm{~mL} / \mathrm{kg}$ when administered i.p. in Swiss albino mice. ${ }^{10}$ Based on these data, we reduced the dose to $2 \mathrm{~mL} / \mathrm{kg}$, and resumed the injections after 48 hours. The lower dose was tolerated relatively well, and the experiment was continued with up to 18 further PEG 200 injections at $2 \mathrm{~mL} / \mathrm{kg}$ doses (Figure 2). Table 2 summarises the observations upon i.p. injection of $2 \mathrm{~mL} / \mathrm{kg}$ PEG 200, which suggest transient pain immediately after the injection, with complete recovery 60 minutes post injection. These observations suggest that PEG 200 can be injected repeatedly i.p. at a dose of $2 \mathrm{~mL} / \mathrm{kg}$ without obvious signs of systemic toxicity, but even this dose causes local pain and suffering.

\section{Discussion}

Organic vehicles such as DMSO have higher toxicity and unwanted side effects compared to isotonic
Table 2. Effects of intraperitoneal injection of PEG 200 at $2 \mathrm{~mL} / \mathrm{kg}$ in mice.

\begin{tabular}{ll}
\hline $\begin{array}{l}\text { Time post injection } \\
\text { (minutes) }\end{array}$ & Observations \\
\hline$>1$ & Signs of pain \\
5 & Signs of pain \\
20 & $\begin{array}{c}\text { Flanks contracted; } \\
\text { restless behaviour } \\
\end{array}$ \\
45 & Flanks contracted; curious \\
60 & Normal behaviour \\
\hline
\end{tabular}

aqueous vehicles, and the injection of DMSO is more painful for the recipient animals. During evaluation of our recent application to perform animal experiments, the local authorities strongly recommended the use of PEG, which they considered harmless, with the intention of replacing DMSO with a vehicle that is better tolerated. Unaware of its toxicity, we complied with this recommendation, and injected PEG 200 i.p. into tumour-bearing mice. Unexpectedly, we observed that PEG 200 was more harmful than DMSO, that the injection of PEG 200 caused pain even at a dose of $2 \mathrm{~mL} / \mathrm{kg}$ and that a dose of $8 \mathrm{~mL} / \mathrm{kg}$ was not tolerated well by the animals.

While generally considered non-toxic when applied orally or dermally or when used in cosmetic products, adverse reactions to PEG have been reported, especially for PEGs with low molecular weight or when PEG has been applied to mucous membranes or damaged skin. ${ }^{2,5-7}$ For example, three burn patients died due to renal failure caused by a burn cream containing PEG. ${ }^{16}$

The toxicity of PEGs injected intravenously as a $5 \%$ solution was found to be very low in rabbits $\left(\mathrm{LD}_{50}\right.$ : 
$10,000 \mathrm{mg} / \mathrm{kg}) .{ }^{17}$ However, few studies have examined the toxicity of parenterally applied PEG in mice. Shideman and Procita compared the toxicity of polypropylene glycols and PEGs. ${ }^{9}$ They report a $\mathrm{LD}_{50}$ of $9.2 \mathrm{~g} / \mathrm{kg}$ for PEG 400 upon i.p. injection into mice - a value for this size of PEG that is also available in Scifinder. ${ }^{9,18}$ In 1965, Worthley and Schott found that the $\mathrm{LD}_{50}$ of PEG 200 was $7.5 \mathrm{~mL} / \mathrm{kg}$ when administered i.p. in Swiss albino mice. ${ }^{10}$ As PEG can reduce plasma volume without altering osmolality, it has been suggested that the lethal effect of parenterally applied PEG is caused by hypovolaemic shock. ${ }^{11}$ We report here that a single i.p. injection of PEG 200 at a dose of $8 \mathrm{~mL} / \mathrm{kg} \quad\left(9 \mathrm{~g} / \mathrm{kg}\right.$; density ${ }_{\text {PEG } 200}=1.125 \mathrm{~g} / \mathrm{mL}$ at $20^{\circ} \mathrm{C}$ ) into mice caused pain and was toxic. The lethality within our population was $50 \%$ (8/16 animals), suggesting an $\mathrm{LD}_{50}$ of $8 \mathrm{~mL} / \mathrm{kg}$, which is slightly above the $\mathrm{LD}_{50}$ reported by Worthley and Schott for PEG 200, and slightly below the $\mathrm{LD}_{50}$ determined by Shideman and Procita for PEG 400. ${ }^{9,10}$ However, the pain that we observed directly after the injection was not reported in previous studies. ${ }^{9,10}$ Clearly, this pain should be considered when the suffering of the animals is assessed.

Our observations suggest that animals injected with PEG i.p. should receive analgesics, although these may distort experimental outcomes. Similarly, use of alternative vehicles requires careful consideration. For example, vegetable oils that contain linolic acid and vitamin $\mathrm{E}$ influence metastasis in vivo. ${ }^{15,19,20}$ Nanocarriers can also be toxic and can bias results. ${ }^{21}$ For example, pegylated phospholipid micelles differentially induce apoptosis in cancerous compared to noncancerous cell lines. ${ }^{22}$

We used a high grade ('BioUltra') PEG solution that is tested to ensure minimal trace impurities below $10 \mathrm{mg} / \mathrm{kg}$, except for sodium (200) and potassium (500). ${ }^{23}$ Assuming a maximum of $500 \mathrm{mg} / \mathrm{kg}$ in the PEG 200 preparation, and given a PEG dose of $9 \mathrm{~g}$ PEG $200 / \mathrm{kg}$ and an average weight of $25 \mathrm{~g}$ per mouse, 0.225 g PEG 200 and approximately $0.1125 \mathrm{mg}$ potassium were applied per animal. The $\mathrm{LD}_{50}$ of $\mathrm{KCl}$ is $15.925 \mathrm{mg} / \mathrm{mouse}$, and no lethality was observed at $12.5 \mathrm{mg} /$ mouse $^{24}$ Thus, the estimated potassium dose that we applied is $1 / 72$ th below the $\mathrm{LD}_{50}$, making it highly unlikely that potassium is responsible for the systemic toxicity that we observed upon injection of PEG 200.

PEG 200 is a mixture of PEGs with an average molecular weight of $190-210 \mathrm{~g} / \mathrm{mol}$ and an average oxyethylene group number of $4.2 .^{2}$ The predominant species in PEG 200 is tetraethylene glycol (CAS number 112-60-7; Figure 1(c)). Due to the manufacturing process, PEG species with a lower molecular weight such as monoethylene glycol (CAS number 107-21-1; 62.07 g/ mol) and diethylene glycol (CAS number 111-46-6;
$106.12 \mathrm{~g} / \mathrm{mol}$ ) can be found in tetraethylene glycol and PEG 200 preparations. ${ }^{25}$ Monoethylene glycol and diethylene glycol are toxic. ${ }^{26}$ When injected i.p. into mice, the $\mathrm{LD}_{50}$ for monoethylene glycol is $5.62 \mathrm{~g} / \mathrm{kg}$, and the $\mathrm{LD}_{50}$ for diethylene glycol $9.73 \mathrm{~g} / \mathrm{kg} .{ }^{27}$ Although information about the content of monoethylene glycol and diethylene glycol in the BioUltra PEG solution we used is not available, other similar products are reported to have a combined monoethylene and diethylene glycol content of $0.4-7 \% .^{28,29}$ Depending on the presence and actual concentration of monoethylene diethylene glycol and diethylene glycol in the BioUltra PEG solution, these two compounds could conceivably contribute to the toxic effects of PEG 200 that we observed. However, even assuming a monoethylene content of $1 \%$ and a diethylene content of $6 \%$, doses of only 0.89 and $0.534 \mathrm{~g} / \mathrm{kg}$, respectively, would have been reached at the beginning of the experiment. These doses represent $1 / 60$ and $1 / 20$ of the $\mathrm{LD}_{50}$ of monoethylene glycol and diethylene glycol, respectively, and would not have been sufficient to cause the toxic effects alone. However, we cannot rule out a contribution of monoethylene glycol and diethylene glycol to the pain we observed upon injection of PEG 200.

A general recommendation for injections in experimental animals is that the solutions should have a neutral $\mathrm{pH}$ of $7.0-7.3 .{ }^{1}$ The poor solubility of our intended test substance meant that undiluted PEG 200 had to be used. When we measured the $\mathrm{pH}$ of the PEG 200 at room temperature, we found that the $\mathrm{pH}$ was between 8.6 and 9.1. However, the impact of $\mathrm{pH}$ varies depending on the route of administration. ${ }^{1}$ Therefore, although a contribution of $\mathrm{pH}$ to the observed pain caused by the PEG 200 injections cannot be ruled out, it is not trivial to predict the actual impact of the $\mathrm{pH}$ on the peritoneum.

Mice injected i.p. with a single dose of $4 \mathrm{~mL} / \mathrm{kg}$ PEG 400 tolerated the treatment, and were killed $1,5,8$ or $24 \mathrm{~h}$ post injection. ${ }^{11}$ Alanine transaminase (ALT) levels were temporarily increased, ascites accumulated and necrosis occurred in the subcapsular regions of the liver. ${ }^{11}$ In our experiment, a lower dose of $2 \mathrm{~mL} / \mathrm{kg}$ PEG $200(2.25 \mathrm{~g} / \mathrm{kg})$ was well tolerated, and no accumulation of fluid in the peritoneal cavity was observed post-mortem. As we did not measure ALT levels in the blood or investigate possible hepatic necrosis, we cannot draw conclusions about possible effects on the liver.

In summary, PEG 200 is not tolerated well when injected i.p. into mice at $8 \mathrm{~mL} / \mathrm{kg}$. At $2 \mathrm{~mL} / \mathrm{kg}$, PEG 200 still induces local pain but can be administered repeatedly without obvious signs of systemic toxicity. Due to the serendipitous nature of our observations, we did not use injection with control substances to assess the toxicity of PEG 200, and therefore our study can formally 
only be considered observational rather than conclusive. Nevertheless, our observations highlight the fact that although PEGs are considered harmless and non-toxic when applied orally or dermally to the undamaged skin, i.p. injections of pure, undiluted PEG are not safe at a dose of $8 \mathrm{~mL} / \mathrm{kg}$, and cause pain even at a dose of $2 \mathrm{~mL} / \mathrm{kg}$.

\section{Acknowledgements}

We gratefully acknowledge the expert technical assistance of Selma Huber and Sabine Müller.

\section{Declaration of Conflicting Interests}

The author(s) declared no potential conflicts of interest with respect to the research, authorship and/or publication of this article.

\section{Funding}

The author(s) received no financial support for the research, authorship and/or publication of this article.

\section{ORCID iD}

Wilko Thiele (D) https://orcid.org/0000-0002-8978-4192

\section{References}

1. Dülsner A, Hack R, Krüger C, et al. Fachinformation aus dem Ausschuss für Tierschutzbeauftragte und dem Arbeitskreis 4 in der TVT. Empfehlung zur Substanzapplikation bei Versuchstieren, 2017, pp.1-7.

2. Rowe RC, Sheskey PJ and Quinn ME. Handbook of pharmaceutical excipients. 6th ed. London: Pharmaceutical Press, 2009, pp.517-521.

3. Kaye TS, Egorin MJ, Riggs CE Jr, et al. The plasma pharmacokinetics and tissue distribution of dimethyl sulfoxide in mice. Life Sci 1983; 33: 1223-1230.

4. Santos NC, Figueira-Coelho J, Martins-Silva J, et al. Multidisciplinary utilization of dimethyl sulfoxide: pharmacological, cellular, and molecular aspects. Biochem Pharmacol 2003; 65: 1035-1041.

5. Smyth HF, Carpenter CP and Weil CS. The chronic oral toxicology of the polyethylene glycols. J Am Pharm Assoc (Sci) 1955; 44: 27-30.

6. Tusing TW, Elsea JR and Sauveur AB. The chronic dermal toxicity of a series of polyethylene glycols. $J \mathrm{Am}$ Pharm Assoc (Sci) 1954; 43: 489-490.

7. Fruijtier-Pölloth C. Safety assessment on polyethylene glycols (PEGs) and their derivatives as used in cosmetic products. Toxicology 2005; 214: 1-38.

8. Food and Agriculture Organization/World Health Organization. Evaluation of certain food additives. Twenty-third report of the Joint FAO/WHO Expert Committee on Food Additives. World Health Organization Technical Report Series Report no. 648, 1980.

9. Shideman FE and Procita L. Some pharmacological actions of polypropylene glycols of average molecular weight 400, 750, 1200 and 2000. J Pharmacol Exp Ther 1951; 103: 293-305.

10. Worthley EG and Schott CD. Pharmacotoxic evaluation of nine vehicles administered intraperitoneally to mice. Lloydia 1965; 29: 23.

11. Pellegrini G, Starkey Lewis PJ, et al. Intraperitoneal administration of high doses of polyethylene glycol (PEG) causes hepaticsubcapsular necrosis and lowgrade peritonitis with a rise in hepatic biomarkers. Toxicology 2013; 314: 262-266.

12. Schempp CM, Kirkin V, Simon-Haarhaus B, et al. Inhibition of tumour cell growth by hyperforin, a novel anticancer drug from St. John's Wort that acts by induction of apoptosis. Oncogene 2002; 21: 1242-1250.

13. Kirkin V, Thiele W, Baumann P, et al. MAZ51, an indolinone that inhibits endothelial cell and tumor cell growth in vitro, suppresses tumor growth in vivo. Int $J$ Cancer 2004; 112: 986-993.

14. Rothley M, Schmid A, Thiele W, et al. Hyperforin and aristoforin inhibit lymphatic endothelial cell proliferation in vitro and suppress tumor-induced lymphangiogenesis in vivo. Int $J$ Cancer 2009; 125: 34-42.

15. Thiele W, Rothley M, Teller N, et al. Delphinidin is a novel inhibitor of lymphangiogenesis but promotes mammary tumor growth and metastasis formation in syngeneic experimental rats. Carcinogenesis 2013; 34: 2804-2813.

16. Bruns DE, Herold DA, Rodeheaver GT, et al. Polyethylene glycol intoxication in burn patients. Burns 1982; 9: 49-52.

17. Smyth HF Jr, Carpenter CP and Shaffer CB. The toxicity of high molecular weight polyethylene glycols: chronic oral and parenteral administration. J Am Pharm Assoc Sci Ed 1947; 36: 157-160.

18. American Chemical Society. Scifinder, https://scifinder. cas.org/scifinder/view/scifinder/scifinderExplore.jsf (accessed 8 January 2019).

19. $\mathrm{Yu} \mathrm{W}$, Jia L, Wang $\mathrm{P}$, et al. In vitro and in vivo evaluation of anticancer actions of natural and synthetic vitamin E forms. Mol Nutr Food Res 2008; 52: 447-456.

20. Liu XH, Conolly JM and Rose DP. Eicosanoids as mediators of linoleic acid-stimulated invasion and type IV collagenase production by a metastatic human breast cancer cell line. Clin Exp Metastasis 1996; 14: 145-152.

21. Hossen S, Hossain MK, Basher MK, et al. Smart nanocarrier-based drug delivery systems for cancer therapy and toxicity studies: a review. $J$ Adv Res 2018; 15: 1-18.

22. Wang J, Fang X and Liang W. Pegylated phospholipid micelles induce endoplasmic reticulum-dependent apoptosis of cancer cells but not normal cells. ACS Nano 2012; 6: 5018-5030.

23. Sigma-Aldrich Corporation. Certificate of analysis Product 88440 Lot BCBS0153V, https://www.sigmaaldrich.com/Graphics/COfAInfo/fluka/pdf/PDF587190. pdf (accessed 16 July 2019).

24. Emmens CW and Marks HP. The effect of sodium and calcium on the toxicity of potassium in mice. $J$ Physiol 1942; 101: 131-135.

25. Aguilar F, Autrup H, Barlow S, et al. Opinion of the scientific panel on food additives, flavourings, processing aids and materials in contact with food on a request from 
the commission related to an application on the use of polyethylene glycol (PEG) as a film coating agent for use in food supplement products. EFSA $J$ 2006; 414: 1-22.

26. Fowles J, Banton M, Klapacz J, et al. A toxicological review of the ethylene glycol series: commonalities and differences in toxicity and modes of action. Toxicol Lett 2017; 278: 66-83.

27. Karel L, Landing BH and Harvey TS. The intraperitoneal toxicity of some glycols, glycol ethers, glycol esters, and phthalates in mice. J Pharmacol Exp Ther 1947; 90: $338-347$.
28. Carolina Internationl Sales Co., Inc. Safety Data sheet: Polyethylene glycol 200, https://www.ciscochem.com/ assets/polyethylene-glycol-200-sds.pdf (2015, accessed 26 March 2019).

29. Merck Group KGaA. Product information on PEG 200, www.merckmillipore.com/DE/de/product/Polyethyleneglycol-200,MDA_CHEM-817001 (accessed 26 March 2019).

\title{
Résumé
}

L'administration parentérale de substances hydrophobes in vivo nécessite l'utilisation de solvants organiques pour assurer une solubilité suffisante et éviter la précipitation. Le diméthylsulfoxyde (DMSO) est couramment utilisé à cette fin. Le polyéthylène glycol (PEG) est généralement considéré comme non toxique, aussi nos autorités de réglementation locales ont récemment recommandé son utilisation à la place du DMSO. Cependant, les souris ayant reçu des injections de $8 \mathrm{~mL} / \mathrm{kg}$ (c.-à-d. $9 \mathrm{~g} / \mathrm{kg}$ ) de PEG 200 par voie intrapéritonéale n'ont pas bien tolérer le PEG 200, et la moitié des animaux ont dû être euthanasiés. Nos résultats montrent que, bien que le PEG 200 soit généralement considéré comme inoffensif, il peut s'avérer toxique lorsqu'il est injecté par voie intrapéritonéale, et douloureux pour les souris. Il peut toutefois être utilisé comme solvant pour injecter des souris de manière répétée par voie intrapéritonéale à la dose de $2 \mathrm{~mL} / \mathrm{kg}$ (c.-à-d. $2,25 \mathrm{~g} / \mathrm{kg}$ ) sans signes de toxicité systémique.

\section{Abstract}

Die parenterale Verabreichung hydrophober Substanzen in vivo erfordert den Einsatz organischer Lösungsmittel, um eine ausreichende Löslichkeit zu gewährleisten und Präzipitationen zu vermeiden. Zu diesem Zweck wird häufig Dimethylsulfoxid (DMSO) verwendet. Ausgehend von der Annahme, dass PEG im Allgemeinen ungiftig ist, wurde uns von der Zulassungsbehörde die Verwendung von Polyethylenglykol (PEG) an Stelle von DMSO nahegelegt. Allerdings vertrugen Mäuse, denen PEG 200 in einer Dosis von 8 mL/kg lentspricht $9 \mathrm{~g} / \mathrm{kg}$ ) intraperitoneal verabreicht wurde, die Substanz nicht. Als Folge musste die Hälfte der Tiere getötet werden. Unsere Ergebnisse zeigen, dass PEG 200, obgleich allgemein als unbedenklich angesehen, bei intraperitonealer Injektion toxisch sein kann und darüber hinaus für die Empfängermäuse schmerzhaft ist. PEG 200 kann aber bei wiederholten intraperitonealen Injektionen bei Mäusen in einer Dosis von $2 \mathrm{~mL} / \mathrm{kg}$ (entspricht 2,25 g/kgl als Lösungsmittel verwendet werden, ohne dass dabei offensichtliche Anzeichen einer systemischen Toxizität auftreten.

\begin{abstract}
o
La administración parenteral de sustancias hidrofóbicas in vivo requiere el uso de disolventes orgánicos para asegurar una solubilidad suficiente y evitar la precipitación. El dimetilsulfóxido (DMSO) se utiliza comúnmente para este fin. Basándose en el supuesto común de que el PEG (Polietilenglicol) no es tóxico, nuestras autoridades reguladoras locales recomendaron recientemente el uso de PEG en su lugar. Sin embargo, los ratones inyectados por vía intraperitoneal con PEG 200 a una dosis de $8 \mathrm{~mL} / \mathrm{kg}$ (es decir, $9 \mathrm{~g} / \mathrm{kg}$ ) no toleraron bien el PEG 200, y la mitad de los animales tuvieron que ser sacrificados. Nuestros resultados demuestran que aunque el PEG 200 se considera generalmente inofensivo, puede ser tóxico cuando se inyecta por vía intraperitoneal, y es doloroso para los ratones receptores. No obstante, puede utilizarse como disolvente para inyecciones intraperitoneales repetidas en ratones a una dosis de $2 \mathrm{~mL} / \mathrm{kg}$ les decir, $2,25 \mathrm{~g} / \mathrm{kg}$ l sin signos evidentes de toxicidad sistémica.
\end{abstract}

